\title{
Networks, Law, and the Paradox of Cooperation
}

BRYAN CAPLAN

EDWARD STRINGHAM

Department of Economics, San Jose State University, San Jose, CA 95192 bcaplan@gmu.edu edward.stringham@sjsu.edu

\begin{abstract}
There is a tension between libertarians' optimism about private supply of public goods and skepticism of the viability of voluntary collusion (Cowen 1992, Cowen and Sutter 1999). Playing off this asymmetry, Cowen (1992) advances the novel argument that the "free market in defense services" favored by anarcho-capitalists is a network industry where collusion is especially feasible. The current article dissolves Cowen's asymmetry, showing that he fails to distinguish between self-enforcing and non-self-enforcing interaction. Case study evidence on network behavior before and after antitrust supports our analysis. Furthermore, libertarians' joint beliefs on public goods and collusion are, contrary to Cowen and Sutter (1999), theoretically defensible.
\end{abstract}

Key Words: networks, anarcho-capitalism, collusion

JEL classification: $\quad$ L13, K42, L15

\section{Introduction}

Cowen and Sutter (1999) argue that libertarian doubts about the viability of collusion are inconsistent. How, they ask, can free-market economists be simultaneously optimistic about the private production of public goods, but skeptical about collusion? Collusion is, after all, a public good vis-a-vis competing firms. Cowen and Sutter's challenge may be dubbed the Paradox of Cooperation: Laissez-faire can cope with either the monopoly or the public good problem, but not both. ${ }^{1}$ Libertarians who dismiss concerns about collusion are at best over-confident.

Cowen (1992) goes further by claiming that in so-called network industries, libertarians are not just over-confident, but wrong: Laissez-faire leads to monopoly, not competition. Although his network industry argument poses a challenge for more moderate libertarians too, Cowen primarily employs it to expose the fundamental weakness of the radical anarcho-capitalist position (Rothbard 1978, Friedman 1989): An excellent example of a network industry is the very free market in defense services that anarcho-capitalists favor. In consequence, anarcho-capitalists are sorely mistaken about the consequences of their ideas if tried.

We maintain that these critiques are thought-provoking but wrong. The dilemmas that Cowen (1992) and Cowen and Sutter (1999) put forward are artificial. Cowen's (1992) network industry argument neglects the deep contrast between prisoners' dilemmas and coordination games; voluntary solutions are self-enforcing for the latter but not the former. Cowen and Sutter's (1999) Paradox of Cooperation likewise glosses over major dissimilarities between collusion and traditional public goods. Empirically, moreover, there is 
little evidence that modern network industries have the collusive powers Cowen ascribes to them. Even before antitrust laws could have deterred collusive behavior, voluntary efforts to restrict competition in network industries were not noticeably more successful than in other areas of the economy.

The paper has the following structure: Section 2 explains Cowen's (1992) network industry argument in depth and discusses responses that take his challenge at face value. Section 3 critiques Cowen's position: There are deep strategic reasons why socially beneficial standardization is easier to orchestrate than socially harmful collusion. Section 4 provides supporting empirical evidence from industry case studies, both before and after the rise of modern antitrust enforcement. Section 5 deconstructs Cowen and Sutter's (1999) Paradox of Cooperation, arguing that libertarians' beliefs about monopoly and public goods can be grounded in sound economic analysis. Section 6 concludes.

\section{Network Industries and Collusion}

\subsection{Cowen's Argument}

The underpinning of Cowen's (1992) critique of anarcho-capitalism is the notion of network industries. In such industries, the value of the good increases as the number of users increases (Katz and Shapiro 1985, 1994, Liebowitz and Margolis 1994). ATM cards, telephones, and software are standard examples. ATM cards grow more useful when the number of ATM machines rises; ATM machines become more profitable to set up as the number of ATM cards in circulation expands. The whole point of owning a phone, similarly, is to call other phone-owners and talk to them. Software file formats are less attractive if no one else can open them.

In a network industry, decentralized provision runs two risks. The best-known is product convergence that locks in a sub-optimal standard (Liebowitz and Margolis 1994). A potentially more destructive problem, though, is proliferation of incompatible products. It would be a serious drawback if a phone produced by one firm could not interface with a competitor's phone, to take a mundane example. Similarly, in an anarcho-capitalist defense services market, it would be disastrous if firms' products were "incompatible"; that is, if competing suppliers shared no procedures for resolving disputes between their respective clients. As Cowen puts it, "The food that I buy from one supermarket is just as valuable to me regardless of whether this supermarket has friendly relations with its competitors; this independence does not hold with private protection agencies" (1992:260).

Monopoly is one way around lock-in and compatibility dilemmas. But there is an attractive alternative remedy: set up an industry "club" or network. Competing firms could then work together, not only to make their products mutually compatible, but to overcome lock-in problems as they arose. Phone companies would agree to interconnect, competing defense firms to peacefully arbitrate disputes using mutually acceptable rules. Proponents of anarcho-capitalism have forcefully maintained that any sensible businessman would do precisely that (Rothbard 1978, Friedman 1989, Benson, 1990). An "outlaw" firm that refused to arbitrate - or recognize unwelcome verdicts-would be reduced to unending warfare with its competitors. 
While Cowen recognizes the benefits of networks, he emphasizes their serious downside. The networks that prod their members towards product compatibility are, as a corollary, well-structured to promote price collusion (Bernheim and Whinston 1985). Voluntary cartels may be notoriously ineffective due to cheating and entry, but networks have a special ability to short-circuit the usual market checks.

Why? A network can punish non-colluders by expelling them from the club, and exclude new entrants by refusing to admit them. Outsiders cannot under-cut the network by selling the same product for less, because services provided outside the network cease to be the same. A phone company with which other companies refuse to connect, or a defense service with which competing suppliers refuse to arbitrate, cannot offer the product consumers want. As Cowen elaborates: "[M]embership in the common arbitration network is one of the most important services an agency can offer its members. Network membership implies that interagency disputes are settled without risk of force or radical uncertainty about the final outcome" (1992:259-260). Firms may remain de jure "independently owned and operated," but for practical purposes there is but one: "In the network the number of truly independent sources of power is likely to be small" (Cowen 1994:331; emphasis added).

The transaction costs of enforcing collusion might be prohibitively high. But if so, it hardly means that laissez-faire works well. When transaction costs preclude collusion, they also rule out simple standardization. After all, why should transactions costs be greater for the former than the latter? The alternative to the orderly cartel is therefore cacophonous competition.

Thus, Cowen (1992) amounts to a virtual impossibility theorem for the efficiency of network industries under laissez-faire. When applied to an anarcho-capitalist defense industry, moreover, his impossibility theorem looks particularly menacing. Low transaction costs in this market lead to far worse than garden-variety monopoly. Since the defense industry, taken as a whole, has a near-monopoly on force, the entire society would be in danger if collusion worked. "Pay the monopoly price or live unprotected" would be a softball threat; a defense cartel could up the ante to "Pay the monopoly price or be reduced to slavery." Anarchy could easily morph into a state of the worst sort. High transaction costs, conversely, would engender not just consumer frustration, but interminable violent conflict between competing suppliers. Cowen's impossibility theorem, as applied to the defense industry, implies that anarcho-capitalism decays into either Hobbes' despotic Leviathan or Hobbes' brutish anarchy.

\subsection{Competition for the Network and Competition Between Networks}

Before turning to the deeper flaws in Cowen's analysis, it is worth considering two less fundamental replies. The first is to appeal to the notion of contestability. Just because a network is the only visible seller does not mean it will act monopolistically. It may be fully constrained by fear of potential competition from a new network.

For defense, though, this claim is unpersuasive. However over-rated the link between competition and number of competitors usually is, the link in an anarcho-capitalist defense industry is very real. Once a group of defense firms earned a large enough market share, they could credibly threaten would-be replacement networks with violence. ${ }^{2}$ Entrants would not 
swarm into the industry as soon as price rose above average cost. They would wait until expected monopoly profits exceeded expected costs of an initial period of warfare. In other words, contestability assumes a legally protected right of entry. A dominant network in the defense industry is in a strong position to suppress this right. Entry remains a lingering threat, but leaves ample leeway for an incumbent network to impose a Hobbesian despotism.

A second reply is that a network industry can often support a number of competing networks. Just because consumers put some value on mutual compatibility does not mean the market will deliver full compatibility. Consumers may value diversity as well as uniformity. Moreover, as Liebowitz and Margolis (1998) point out, diseconomies of scale can outweigh the pressure for a single network.

The Windows and Macintosh operating systems co-exist. So do multiple languages. Why not multiple anarcho-capitalist defense networks? Cowen specifically mentions the case of McDonald's restaurants, observing that "Different franchises of McDonald's, for instance, enter into common relations through the parent company and agree not to compete with each other" (1992:261). But McDonald's is only one fast-food franchise out of hundreds! Even if chain restaurants controlled $100 \%$ of the market, the chains would still compete with each other.

Unfortunately, competing defense networks, if viable, appear to run once again into Cowen's impossibility theorem. Disputes between networks' respective clients will inevitably arise. If transactions costs are low, the rival networks will reach mutually acceptable procedures for resolution. But once again, why stop there? Why not go further and strike deals to suppress price competition and scare off prospective entrants? In contrast, if transaction costs are high, this means chaos, not ordered anarchy. Finding negotiation too costly, the competing networks resort to violence.

\subsection{Friedman's Reply}

David Friedman (1994) raises a simple but critical doubt about the link between network goods and collusion. Suppose there are $N$ firms in a network industry. Then even a complete set of $N(N-1) / 2$ bilateral contracts between competitors is not equivalent to one $N$-firm multilateral contract. Each bilateral contract maximizes the joint profits of the two signatories, ignoring the interests of the other $(N-2)$ firms. The signatories have a mutual interest in avoiding conflict with each other, so we should expect their contracts to handle dispute resolution. But they have almost no incentive to write collusive contracts, because virtually all of its benefits spill over onto the other $(N-2)$ firms. As Friedman explains:

Nothing in this situation requires or implies a single firm controlling the whole, nor anything analogous to one. The network as I have described it has no decision-making body. Its "decisions," the set of legal codes it enforces, are the outcome of independent profit making decisions by the individual firms and bargaining between pairs of firms.

Nothing in the logic of the market for protection and arbitration implies that the outcome will maximize the summed profits of the firms, as Cowen seems to assert (1994:323).

Friedman undercuts any claim Cowen might have to an impossibility theorem. But one could retreat to the more moderate position that a single $N$-firm multilateral contract would 
probably have lower transactions costs than $N(N-1) / 2$ bilateral contracts. One centralized clearinghouse may cost less than $N(N-1) / 2$ bilateral bank clearing contracts, and one centralized arbitration network may cost less than $N(N-1) / 2$ arbitration contracts. If so, an unregulated market delivers one $N$-firm contract and, as per Cowen's argument, endogenously moves to the collusive outcome. The next section tries to meet this claim head-on by arguing that even if the market delivers one $N$-firm contract, the resulting network would focus on standardization, not collusion.

\section{The Limits of Networks: Self-Enforcing Agreements and Beyond}

Two jointly exhaustive inferences form the backbone of Cowen's thesis. First, "If the network can implement successful sanctions against outlaws, however, the network can also implement successful sanctions against potential competitors"; second, "If punishing potential competitors is too costly, punishing outlaws is also too costly" (1992:259). The underlying premise is that outlaws and potential competitors are equally costly to punish. Initially, this looks highly plausible. How could it be wrong? Consider one of the most frequently invoked sanctions: the boycott (Rothbard 1978, Benson 1990). Can the nature of a boycott's target affect the costliness of making it work?

Absolutely. Let us distinguish two kinds of boycotts: self-enforcing and non-selfenforcing (Telser 1980). A good example of the former is a boycott against a crooked businessman. To maintain it, publicity alone is likely to suffice; no one wants to continue dealing with a known cheat ${ }^{3}$ (Veitch 1986, Greif 1993, Benson 1993, Greif, Milgrom and Weingast 1994, Stringham 2003). Note further that the business community does not need to carefully monitor its members to enforce such a boycott. The cheater's former victims think, in effect, "Fool me once, shame on you; fool me twice; shame on me"; but those with no prior dealings with the cheater similarly reason, "Fool him once, shame on you; fool me once, shame on me." If defense firm A reneges on an arbitration bargain with defense firm B, it alienates not just B, but its full array of actual and potential trading partners. By breaking the rules, cheaters ipso facto reduce the profitability of trading with them. Other businesses punish them not out of sympathy with the victim, but from their proverbial regard to their own self-interest.

On the other hand, a good example of a non-self-enforcing boycott would be a refusal to deal with redheads. As long as "being a redhead" is uncorrelated with "being a bad business risk," it is more profitable for an individual merchant to break the boycott than keep it. Hatred of redheads is likely to be heterogeneously distributed; but more fundamentally, even if anti-redhead preferences were equally intense, boycotting them would be a public good. Simple publicity about the existence of redheads consequently falls on deaf ears. It would take more drastic measures to sustain the boycott: mutual monitoring to detect profit-driven violations of the boycott, "courts" to weigh evidence, and secondary boycotts to punish those "found guilty."

So the nature of a boycott's target matters. It is cheap to orchestrate self-enforcing boycotts of the dishonest, but expensive to orchestrate non-self-enforcing boycotts of redheads. In fact, incentives parallel those for statistical versus taste-based discrimination (Coate and Loury 1993). Cowen's line of reasoning could easily lead us to think that: "If the market 
can sustain discrimination against contract-breakers, however, the market can also sustain discrimination against redheads. If discriminating against redheads is too costly, discriminating against contract-breakers is too costly." This overlooks the interaction between the nature of the target and the costliness of discrimination. Competitive pressure reinforces statistical discrimination based on real group differences: People who broke contracts in the past are more likely to break them in the future. But competitive pressure dissolves purely taste-based discrimination (Sowell 1994): Redheads' dollars are as good as anyone's. Unregulated markets are neither generically "discriminatory" nor "non-discriminatory." One form thrives, the other withers.

The same point holds for networks; it is easy to reach some types of cooperation, even as the cost of others remains prohibitive. Consider the classic contrast between prisoners' dilemmas and coordination games. Every industry faces a prisoners' dilemma: Firms within an industry can earn more profits if they all collude, yet individual firms earn more if they continue to compete. Coordination problems are less ubiquitous. They surface when consumers want compatibility: DVDs that play in their DVD players, ATM cards that work in unfamiliar ATM machines, or a defense firm that subscribes to a common body of procedures for dispute resolution.

The difficulty of solving the two classes of problems hinges on self-enforcement. In coordination games, maintaining a cooperative outcome is fairly simple. If other banks issue ATM cards of standard dimensions, an oddball bank that refuses to conform hurts only itself. The reverse holds in prisoners' dilemmas. The temptation to defect actually rises with the expected extent of cooperative play. ${ }^{4}$ If all of the other banks collude to charge exorbitant fees, profits of the deviant bank that under-cuts them go up. True, the banking network might off-set incentives to defect with extensive monitoring and punishment; but solving coordination problems is far easier.

It is worth pursuing this point at length because Cowen maintains that networks' ability to standardize products is ipso facto evidence of their ability to collude:

The ability to collude is inherent in the nature of the network. The network can internalize the externalities problem behind peaceful adjudication only by suspending quality competition - that is, by offering a uniform set of laws or higher-order adjudication procedures. The ability to engage successfully in quality collusion, however, implies that other kinds of collusion are possible also (1992:259).

Cowen here conflates two radically different sorts of business cooperation under the generic heading of "collusion." Standardizing products is essentially a coordination game, fixing prices a prisoners' dilemma. As long as consumers want a uniform product, adhering to industry standards is self-enforcing. As long as consumers prefer to pay less rather than more, price-fixing is not. Ability to reach the cooperative outcome in the former in no way "implies" ability to reach it in the latter. ${ }^{5}$

Cowen makes the strong claim that it is inconsistent to believe in only one: "But if collusion, one public good among agencies, cannot be provided, neither can the punishment of renegades be provided, another public good among agencies. We cannot have it both ways" (1994:331). This inconsistency is illusory: When firms peacefully resolve disputes 
and ostracize renegades, it is selfishly optimal behavior in a coordination game, not civicminded production of a public good.

Cowen conflates standardization and collusion in a second way. By labeling product uniformity "quality collusion" he makes it sound as if the goal is to hold product quality down. But isn't uniformity better seen as an aspect of quality? Consumers' preference for standardized products is the motive to have a network in the first place (Liebowitz and Margolis 1995).

On reflection, Cowen would probably acknowledge this, but retreat to the position that network formation remains a "Faustian bargain": Centralization raises product quality by sacrificing the familiar benefits of competition. But this Faustian trade-off may not even exist, because coordination problems are, compared to prisoners' dilemmas, readily solved. Any network strong enough to enforce collusion will be at least strong enough to realize the benefits of uniformity. The reverse is not true: Ability to standardize-to overcome mere coordination problems - hardly indicates ability to suppress ordinary competition.

Stepping back, imagine graphing — in the spirit of Cowen and Sutter (1999) - the feasible extent of cooperation as a function of its cost. Cowen effectively partitions this graph into two regions (Figure 1). If the costs of cooperation are low, as in Region 1, bargains of all sorts flourish-including some with large negative externalities. If the costs of cooperation are high, as in Region 2, mutually beneficial interaction is impossible. There is a collapse into chaos.

The distinction between coordination games and prisoners' dilemmas-more generally, self-enforcing versus non-self-enforcing interaction-highlights a better way to conceive the relationship between cooperation and its cost. Imagine splitting the graph into three

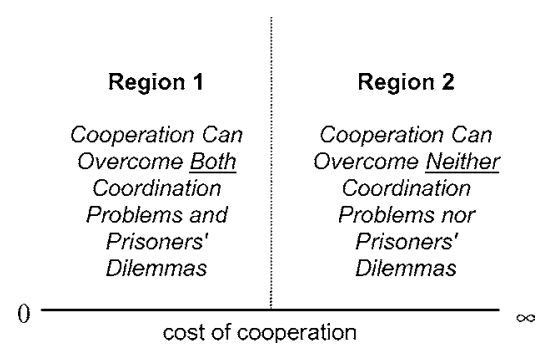

Figure 1. The cost and extent of feasible cooperation.

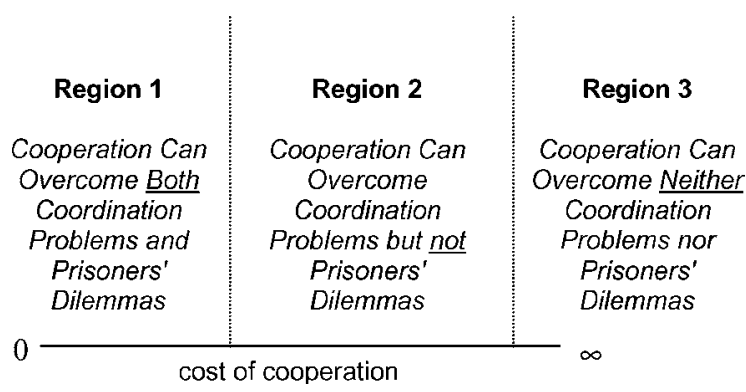

Figure 2. The cost and extent of feasible cooperation. 
regions rather than two (Figure 2). In Region 1, the costs of cooperation are extremely low. It is cheap to reach and enforce agreements-even collusive agreements that require numerous actors to fix prices or attack new entrants. In Region 3, the costs of cooperation are extremely high. Elementary forms of coordination, like language and measurement, fail to arise. But Cowen (1992) and Cowen and Sutter (1999) neglect Region 2, where the costs of cooperation are intermediate: High enough to prevent collusion, low enough to permit coordination. The remainder of the paper argues that this intermediate case is not only logically possible but empirically dominant.

\section{Evidence from Network Industries}

Cowen's case is almost wholly theoretical. The usual historical evidence on collusion under laissez-faire, he maintains, cannot be credibly extended to network industries: "Although private cartels usually collapse of their own accord, most historical examples of cartel instability do not involve the benefits of joining a common network" (1992:260). But Cowen provides little in the way of empirical counter-examples to support his belief that networks industries are different. ${ }^{6}$

This section takes a preliminary look at modern and historical network industries. While they definitely standardize products in beneficial ways, there is little evidence that network industries are more prone to collusion than non-network industries. Instances of attempted and temporarily successful collusion do surface. But collusive efforts in network industries appear neither more common nor more successful than in other sectors of the economy (Dewing 1914). A full-blown comparative history of collusion in network and non-network industries is beyond the scope of this paper. On Cowen's account, however, the contrast should be too large to miss.

The exercise remains probative, we maintain, in spite of the special potential for anticompetitive violence in the defense industry. Once a single network reaches the collusive outcome, it might be able to enforce collusion and deter entry with the threat of violence. The critical question, though, is whether decentralized firms can bootstrap themselves into this dominant position. This is Tullock's (1974) "paradox of revolution" in another guise. After a violent movement gets off the ground, it can use violence to reinforce its position by extorting help from fence-straddlers. The hard part is getting a violent movement off the ground in the first place. In other words, saying that violence solves the free-rider problem begs the question: Violent threats are only credible after the free-rider problem has been non-violently solved to a moderate degree. While the potential for violence under anarchocapitalism raises special issues, these will probably not materialize unless it is abnormally easy for networks to peacefully collude first.

\subsection{Modern Networks: The Credit Card Industry}

The market for credit cards has all the defining characteristics of a network industry (Carlton and Frankel 1995a, 1995b, Economides 1995, Evans and Schmalensee 1995, 1999). The value of a credit card increases with the number of participating consumers, merchants, and banks. As Evans and Schmalensee (1999:138) observe, "[P]ayment cards are provided 
through a network industry in which participants are linked economically in unusual ways. Payment cards are useless to consumers unless merchants accept them, but merchants have no reason to accept cards unless consumers carry them and want to use them." Consumers value widely accepted payment cards more, so issuers typically belong to large networks. But competition persists (Stringham 1999, Zywicki 2000). The market sustains inter-network competition between networks owned by member banks, such as Visa and MasterCard, proprietary networks like Discover and American Express, and store-specific cards.

What is more striking is the scope of intra-network competition. Visa and MasterCard, the two leading networks, are non-profit membership corporations with thousands of member firms. They provide infrastructure and a large network of users, and finance their services with membership fees (Hausman et al. 1999; Carlton and Frankel 1995:646). Despite strong network features, there is vigorous intra-network competition (Rochet and Tirole 2000). Evans and Schmalensee (1995:889) note that:

Given the inherent interdependency of transactions, how - if at all—should the costs, risk, and income from the 'two sides' of the business be shared? In theory, the problem could be addressed by having the organization (e.g., Visa) establish the terms (i.e., interest, annual fee, special features) for all Visa cards issued by any member as well as the discount rate to be paid by the merchants... Such an approach, however, would be far more restrictive on competition at the intrasystem level than is desirable (or, perhaps, even legal). Therefore, neither Visa nor MasterCard regulates the amount charged to cardholders by its various issuers or the amount of discounts paid by merchants.

Though one might expect the network to impose monolithic restrictions, member firms have a lot of autonomy. Members cooperate to make the product more convenient, not to stop them from stealing each other's customers. Visa founder Dee Hock (1999) explains that Visa was deliberately designed to allow intra-network competition. According to Evans and Schmalensee (1995:865-866):

Competition for consumers takes place between issuers of Visa and MasterCard... Nationally, there are approximately 7,300 Visa issuers, each of which sets its own interest rates, fees, features, and marketing strategy for its cards. Although many payment cards are marketed locally, there are also nearly 100 national issuers, including all the largest Visa and MasterCard issuing members... Competition to enroll merchants to take a Visa or MasterCard brand and to service these merchants took place among approximately 250 acquirer organizations.

The benefits of network membership are great. But this hardly induces the networks to "squeeze" aspiring members, or subject them to draconian restrictions. Broad membership is what makes it valuable to join in the first place. The natural way for networks to build and maintain such a membership base is a "big tent" approach, where affiliating is cheap and low-hassle. If one network's rules create a lot of outsiders, a more inclusive network comes along to take advantage of the situation. In the fifties, Diners Club created the first charge card network among Manhattan restaurants (Evans and Schmalensee 1999:62). Visa originated in 1966 when the Bank of America licensed its card nationally and shortly spun off 
its franchise system to create a nonstock membership corporation (Evans and Schmalensee 1999:66). MasterCard has similar origins. It was a cooperative effort to induce many banks, merchants, and consumers to jointly adopt the new card. Decades later, alongside a handful of existing networks, Sears leveraged its store card to create Discover. Following the "big tent" approach, Discover offered such attractive rates that it became as widely accepted as American Express shortly after its creation, turning profitable three years later after a $\$ 300$ million investment (Evans and Schmalensee 1999:232).

The credit card industry thus provides little support for Cowen's fears. But while evidence from modern examples can hardly be dismissed, antitrust is a troubling confounding variable. The checkered history of antitrust makes us doubt that the Department of Justice deserves credit for the accomplishments of the credit card industry ${ }^{7}$ (McChesney and Shughart 1995). Still, perhaps Visa and MasterCard permit intra-network competition because they must. It is therefore in many respects more probative to examine networks during the era prior to modern antitrust enforcement.

\subsection{Networks Before Antitrust: Clearinghouses}

Banking is a good example of a nineteenth-century network industry. Competing banks formed clearinghouses to enhance the value of their product. As Timberlake (1984:2-3) explains, "Instead of each bank establishing a transactional relationship with all other banks, every bank sends a representative to one place — the clearinghouse - where its debit items are cleared against its credit items." Gorton (1985), Gorton and Mullineaux (1987), and Calomiris (1990) emphasize another function: Since the leading reasons for bank failure were fraud and conflict of interest (Calomiris and Kahn 1991), banks needed a way to signal honesty. One good signal was joining a banking network liable for member obligations, conditional on adherence to its rules. As Calomiris puts it, banks used "self-regulation, made credible by mutual liability" (1990:283).

In the pre-antitrust U.S. banking industry, then, networks known as clearinghouses arose to reduce transactions costs and bolster reputations. "An essential feature of the banking industry was the endogenous development of the clearinghouse, a governing association of banks to which individual banks voluntarily abrogated certain rights and powers normally held by firms" (Gorton 1985:277). Membership requirements and monitoring enhanced the public's trust in the redeemability of members' bank notes and the overall soundness of their business practices. As Gorton and Mullineaux (1987:461) explain:

The clearinghouse required, for example, that member institutions satisfy an admissions test (based on certification of adequate capital), pay an admissions fee, and submit to periodic exams (audits) by the clearinghouse. Members who failed to satisfy [commercial-bank clearinghouse] regulations were subject to disciplinary actions (fines) and, for extreme violations, could be expelled. Expulsion from the clearinghouse was a clear negative signal concerning the quality of the bank's liabilities.

Did the threat of expulsion from the clearinghouse lead to a blatant pattern of industrywide collusion? No; as Dowd (1994:298) puts it "Nor is there any strong evidence, populist views about banking power notwithstanding, that banks were able to cartelize the market 
successfully." Banks that tried to set rates found it difficult to punish cheating and provoked fierce competition.

Consider the case of the New York Clearinghouse, which decreed, in 1873, that "No bank shall pay, or procure to be paid, interest upon deposits" (Sprague 1910:102). Things did not play out as expected. As Sprague (1910:104) recounts:

The report of the clearinghouse committee seems to have been received with general approval, both by bankers and by the public, but it led to no immediate change in banking methods. It was considered at a meeting of the banks... and the adoption of its principal recommendation, that interest on its deposits be prohibited, was favored by about three-fourths of the banks. It was felt, however, that a unanimous agreement was necessary to secure its effective adoption.

In 1884, American Exchange National Bank president George Coe complained, "This subject has upon several occasions in years past been under consideration, and its total abolition has been almost unanimously agreed to among banks by written contract. Yet by the refusal of one or more members it has failed to become a binding obligation" (Sprague 1910:375). Rate-fixing banks would lose out to those offering competitive rates. Expelling rate-cutters would have been legal, but apparently members saw it as imprudent. Excluding financially impeccable members would dilute the network's reputation for financial probity. Far better to keep transactions costs low by sticking to an inclusive, "big tent" approach.

In another scheme a clearinghouse tried to fix rates of exchange. This too was unsuccessful:

But the formation of new banks finally played havoc with the uniform-rate system. While it lasted, it was obligatory upon every [member] bank, but in 1891 the newly organized banks began to cut on rates. The clearing-house members endeavored to induce the new banks to join the association, but did not at first succeed. It was regarded as unjust to the member banks to hold them to the existing agreement when their competitors were free, and accordingly, in June, 1891, the schedule of rates was made no longer obligatory (Cannon 1910:15).

An additional check against collusion was banks' credible threat to withdraw from the network or refuse to join. As Dowd recounts:

A good example of banks "voting with their feet" even when the market could only support one clearinghouse is provided by the demise of the Suffolk system. The Suffolk system was a club managed by the Suffolk Bank of Boston, but some members found the club rules too constraining and there were complaints about the Suffolk's highhanded attitude toward members. Discontent led to the founding of a rival, the Bank of Mutual Redemption (BMR), and when the latter opened in 1858 many of the Suffolk's clients defected to it (Dowd 1994:295).

Despite the benefits of participation, then, a dominant clearinghouse hardly had a stranglehold on uppity members. Since one of a clearinghouse's main selling points is breadth 
of membership, they mostly stuck to issues where member banks could broadly agree. ${ }^{8}$ Expelling financially unstable firms makes the network more attractive for consumers; expelling up-and-coming firms makes it less attractive. Conditioning membership on factors other than financial honesty dilutes the value of the name brand of the network.

So clearinghouses took a soft-line on some issues, like cutting rates. But they took a hardline on others. They had no qualms about ousting insolvent banks. Calomiris (1990:288) explains that, "The Indiana insurance system relied on bankers themselves to make and enforce laws and regulations through a Board of Directors and, importantly, gave the board authority when to close a bank. Unlimited mutual liability provided bankers the incentive to regulate and enforce properly." Because consumers knew that unreliable banks would be penalized, it raised "the public's perception of the quality of the 'average' bank" (Gorton and Mullineaux 1987:463). Thus, clearinghouses were bad at orchestrating some forms of cooperation, but good at others.

During banking panics, the power of clearinghouses expanded. But this was temporary by design:

Suppose that once the more hierarchical form of organization had been adopted during the panic, the [clearinghouse] did not revert back to its more limited form. Then individual banks, knowing that the loan certificates were available, would have an incentive to make riskier loans since each would believe that the risk could be spread over the other members through the loan certificate process. Clearly, this would not be viable... Only by reverting back to the more limited organizational form did individual banks have the incentives to monitor each other (Gorton and Mullineaux 1987:466).

For Gorton (1985:283) "the existence of the clearinghouse suggests that private agents can creatively respond to market failure." At the same time, the historical evidence disconfirms Cowen's belief that a new—and perhaps worse-market failure accompanies each of the market's "creative responses."

\subsection{The Sports League Anomaly}

There are numerous other examples of competitive network industries: ATM machines, computer software, computer hardware, fax machines, financial exchanges, ${ }^{9}$ the Internet, television, telecommunications, and more. Geddes (2000) surveys utilities and network industries such as airlines, cable television, railroads, telecommunications, and trucking, and concludes that laissez-faire outperforms state control. ${ }^{10}$ There is however one cluster of network industries where collusion has been fairly effective: professional and college sports $^{11}$ (Boal and Ransom 1997, Salop and White 1991).

The rules of sports leagues are often expansive. They address salaries, player mobility, television contracts, revenue sharing, location, and more. The underlying threat is expulsion of disobedient teams. (NCAA Division I Manual 2000-2001: Article 19). High-profile defiance does surface: in NCAA v. Board of Regents, for instance, a group of large schools negotiated their own television contracts in spite of NCAA rules. Nevertheless, Cowen's pessimistic scenario for network industries is often consistent with economic histories 
of sport (Noll 1974). Leagues impose collusive rules and teams take sanctions for noncompliance seriously.

There is however an alternative explanation for their successful collusion: Professional sports are superstar markets (Rosen 1981). A vital characteristic of their product, for many fans, is that the contending teams are "the best." While there is obviously a market for minor league games, college sports, and so on, consumer interest declines rapidly with the quality of play.

Given these consumer preferences, collusion gets a lot easier. The supply of good players is elastic, but the supply of "the best" players is extremely inelastic almost by definition. A league where a moderate number of teams employ almost all of the "best" players is like a natural resource cartel. This does not make it any less laborious to initially reach a collusive agreement. But it multiplies the present value of success, because the monopoly profits of natural resource cartels are so persistent. There is little need to worry about entry. As long as demand to watch the sport's best players endures, a cartel can earn monopoly profits indefinitely.

If this hypothesis is correct, the effectiveness of collusion in professional sports is no cause for concern about network industries in general. ${ }^{12}$ Network industries might function poorly when they also happen to be superstar markets. But this is a rare combination. Few consumers care much if their bank or credit card company is "the best." Networks in these industries are accordingly unlikely to successfully jump from coordination to collusion.

Would anarcho-capitalist defense services turn out to be a superstar market? Conceivably so: Free-market defense, like legal representation in the current world, would be a positional good to some degree. Consumers might feel safer with the best firm standing behind them. This pushes the market in a superstar direction. But the effect is probably slight: Few people today see the need to hire "the best" law firm, in spite of the positional nature of legal representation. ${ }^{13}$ Similarly, many consumers opt for low-quality, low-cost security in today's marketplace, despite the positional aspects of protection (Benson 1998).

\section{The Paradox of Cooperation Resolved}

Let us now return to Cowen and Sutter's paradox:

Free market economists typically express confidence in the ability of markets to produce public goods... At the same time, free market economists tend to be pessimistic about the stability of cartels in an unregulated market. If markets successfully produce local public goods, however, why are stable cartels not more prevalent? (1999:168)

So far, our implicit response has been: Yes, it is hard for markets to produce public goods, but private provision of defense services functions well as long as free markets possess the humbler ability to solve coordination problems. In other words, the externalities of social order are infra-marginal. If farmers grew no food, or if defense providers failed to develop procedures for dispute resolution, society would collapse into chaos. Yet these dire situations are unlikely at the laissez-faire level of output. 
On reflection, though, this response is too pessimistic. Common sense tells us, and experimental studies verify, that voluntary production of public goods is a reality (Schmidtz 1991, Smith 1980). What makes this possible? There are two critical variables we would advance: (a) the effectiveness of partial participation, and (b) ideological appeal. Furthermore, along both dimensions, voluntary provision of traditional public goods like clean air usually has a decisive advantage over voluntary collusion.

First consider the effectiveness of partial participation. Voluntary collaboration never yields unanimity. But how injurious is the shortfall? This hinges on the elasticity of outsiders' behavior. Suppose that $50 \%$ of all firms in an industry join a cartel to restrict production. They will be unable to raise prices much because outsiders' supply curves will typically be elastic. Firms that refuse to join the cartel increase their output to exploit the situation. Indeed, if outsiders' supply is perfectly elastic, strict unanimity is crucial; any departure from $100 \%$ participation renders the cartel impotent. In contrast, if 50\% of all people who benefit from clean air decide to "do their part" by buying low-pollution cars, they can make a significant dent in the problem. As long as the outsiders already pollute to the selfishly optimal point, an improvement in the level of air quality has no effect on their marginal incentive to pollute. Half of the drivers pollute less; half pollute the same; air quality improves. Of course, neither the cartel nor the clean air movement fully solves its public good problem. The point is that voluntary pollution abatement is a partial success, whereas the voluntary cartel is a full failure.

Admittedly, outsiders' supply of a product is occasionally less elastic: A natural resource cartel may be moderately effective in spite of partial participation, at least in the short-term. Similarly, outsiders' response to altruism might be more elastic: Donations to relieve world hunger could elicit a Malthusian population response, leaving the level of starvation insensitive to charitable giving. We can also imagine a crowding out of altruism, so that if some people give more, others offset it by giving less; or, even more perversely, charities might have conflicting goals (e.g. socialist and libertarian think tanks). But for most purposes, we should expect outsider elasticity to be high for products but low for causes. After all, the more successful a cartel is, the more profitable it becomes to break it; but increases in charity rarely make it more profitable to exacerbate the very ills the donations were intended to alleviate.

The effectiveness of partial participation warrants optimism only if participation rises above the selfishly optimal level—none—in the first place. This is where ideological appeal makes it entrance. Empirically, people typically are-to a minor extent-willing to make trade-offs between their narrow self-interest and their ideological beliefs (Tullock 1981). In spite of their diversity, moreover, ideological commitments are not random. This gives rise to the second asymmetry between cartels and more familiar public goods: While many people willingly sacrifice to help the environment, combat world hunger, expel foreign oppressors, or promote human liberty, few want to crusade for the maximization of their industry's total profits. Investors have occasionally heeded calls to forego profit for a public-spirited cause, from turnpike construction in the 19th century (Klein 1990) to "social investing" in the 21 st. ${ }^{14}$ Exhortations to forego profit for the benefit of fellow investors do not have the same moral resonance. A general account of why some causes-but not others-elicit charity is beyond the scope of this paper. But there can be little doubt that this contrast is real. 
Cowen and Sutter (1999) wonder how free market economists can be optimistic about voluntary public good provision, but skeptical about the prospects of voluntary cartels. A natural explanation is wishful thinking. We argue, in contrast, that both beliefs are reasonable. Cartels are unlikely to work with partial participation, and in any case enjoy little ideological loyalty. More familiar public goods, in contrast, cope better with partial participation, and are, due to ideological appeal, more able to win voluntary support.

\section{Conclusion: Public Opinion as a Public Good}

Cowen and Sutter put forward a final, more challenging, paradox: "[L]ibertarians believe that voluntary institutions do not necessarily produce the public good of mobilizing public opinion against excess government intervention" (1999:169). This point must be granted. But it impinges only on the difficulty of establishing a libertarian society. It does not show that it would be unstable once established. It does not even show that the costs of transition outweigh the benefits. By itself, the paradox practically amounts to, "It is a good idea, but it will never be." Maybe so, but it is worth pointing out the endogeneity: If widely accepted, this paradox would seem to be self-defeating. Once enough people see something as a good idea, it generally happens.

\section{Acknowledgment}

We would like to thank Peter Boettke, Tyler Cowen, Robin Hanson, John Hasnas, Dan Sutter, and two anonymous referees for numerous helpful comments and suggestions. Scott Beaulier provided excellent research assistance. The standard disclaimer applies.

\section{Notes}

1. It is worth mentioning that Cowen and Sutter (1999) critique a wide spectrum of political positions, and find comparable inconsistencies in a variety of non-libertarian viewpoints.

2. Sutter (1995) makes a stronger version of this claim. In his model of the "Protection Racket Game," firms can credibly threaten violence even when there are no network externalities and the market for defense services is highly decentralized. While we doubt that the bad equilibria in Sutter's model would be focal, developing this argument must be left for future research.

3. The boycott victim could naturally offer, instead, to compensate prospective business partners for the extra risk of trading with a known cheat. But the incentive structure is essentially the same: Publicity alone leads the business community to make cheaters worse off.

4. Entry amplifies the contrast between coordination games and prisoners' dilemmas. The existence of common standards does not spur entry, and new entrants have every reason to adhere to prevailing standards. The opposite holds for price collusion. Artificially high prices raise the incentive to enter, and new entrants' standard strategy is to upset pre-existing industry practices by under-pricing incumbent firms.

5. There is a standard list of factors that make collusion easier to achieve. Some of these are likely to make coordination easier as well: most obviously, a small number of firms and ease of communication. Others probably make little difference: legal restriction of entry makes collusion easier, but probably has little effect on coordination. Unless incumbents have "locked-in" an inferior standard, a new entrant has a clear incentive to make its products compatible with those already on the market.

6. Cowen (1994:331) observes that "[T] he reason we observe [governments] so frequently is because they are the predominant form that a stable equilibrium takes." But this hardly counts as empirical evidence for Cowen's 
network industry hypothesis. The ubiquity of government is equally consistent with virtually every account of its origin. For example, one might argue that government universally exists because the public supports it existence, and policy tends to match public opinion.

7. There have been several major antitrust challenges in the credit card industry, though their connection to "competition" is questionable. In 1975, the US DOJ forced Visa and MasterCard to permit dual membership, or "duality." But in 1998 the DOJ initiated a suit to forbid duality (Hausman et al. 1999). A recent lawsuit by Discover against Visa and MasterCard focuses on interchange fees (Carlton and Frankel 1995a, 1995b). Visa and MasterCard maintain that their fee structure is necessary to cover the costs of running the networks and discourage free riding (Evans and Schmalensee 1995, Allen 2000, Hanft, 2000).

8. With identical firms, of course, strict collusive rules can enjoy unanimous support. But in the real world, the benefits of collusion are far from uniform; up-and-coming firms, for example, tend to lose out (Libecap and Wiggins 1984).

9. The evidence on financial exchanges' ability to effectively fix commission rates is more ambiguous than the other cases and demands further research. From their beginnings, exchanges in London and New York faced competition from other exchanges and brokers who were not members of any exchange (Stringham 2002, Banner 1998). In 1792, a handful of New York brokers agreed to fix commission rates with the Buttonwood Tree Agreement. The attempt failed, but common rates became the norm in 1817, and continued through the 1934 inception of the SEC. In London fixed commission rates eventually fell apart on their own. Perhaps fixed rates lasted so long in New York (Mahoney 1997) because they differentiated members from less reputable bucket-shops.

10. See also Lal (1997). Gabel (1994) points to government regulation as a major reason that competing telephone networks ended in monopoly. Mahoney (1997) likewise argues that the SEC propped up brokerage commissions above market rates.

11. Cowen has raised this point in several informal exchanges.

12. Indeed, the effectiveness of collusion in professional sports may be actually be efficiency-enhancing. Most obviously, league rules increase the entertainment value of sporting events by creating more evenly-matched teams (Neale 1964, Fort and Quirk 1995).

13. Perhaps the relevant positional variable, though, is not absolute quality, but size. Consumers might feel safer with the largest firm protecting them, instead of the tenth largest. Empirically, again, this does not seem like a big factor. Larger auto insurers, for instance, have more legal resources to defend their clients than small insurers, but purchasers of insurance rarely care about firms' relative size. The reason, presumably, is that large firms also have proportionally more demands on their resources. The threat of bringing the totality of their resources to bear on a single case is not credible.

14. We would like thank an anonymous referee for bringing the first example to our attention.

\section{References}

Allen, P. (2000) "Prepared Testimony of Mr. Paul Allen.” Senate Banking Committee, Subcommittee on Financial Institutions, Hearing on Competition and Innovation in the Credit Card Industry at the Consumer and Network Level, May 25, 2000.

Banner, S. (1998) “The Origin of the New York Stock Exchange, 1791-1860.” Journal of Legal Studies, 27: 113-140.

Benson, B. (1990) The Enterprise of Law. San Francisco: Pacific Research Institute for Public Policy.

Benson, B. (1993) "The Impetus for Recognizing Private Property and Adopting Ethical Behavior in a Market Economy: Natural Law, Government Law, or Evolving Self-Interest." Review of Austrian Economics, 6: 43-80.

Benson, B. (1998) To Serve and Protect: Privatization and Community in Criminal Justice. New York: New York University Press.

Bernheim, D. and Whinston, M. (1985) "Common Marketing Agencies as a Device for Facilitating Collusion." Rand Journal of Economics, 16: 269-281.

Boal, W. and Ransom, M. (1997) “Monopsony in the Labor Market.” Journal of Economic Literature, 35: 86-112. Calomiris, C. and Kahn, C. (1991) "The Role of Demandable Debt in Structuring Optimal Banking Arrangements." American Economic Review, 81: 497-513. 
Calomiris, C. (1990) "Is Deposit Insurance Necessary? A Historical Perspective." Journal of Economic History, 50: 283-295.

Cannon, J. G. (1910) Clearing Houses. Washington, Govt. Print. Off.

Carlton, D. and Frankel, A. (1995a) “The Antitrust Economics of Payment Card Networks." Antitrust Law Journal, 63: 643-668.

Carlton, D. and Frankel, A. (1995b) "The Antitrust Economics of Payment Card Networks: Reply to Evans and Schmalensee Comment." Antitrust Law Journal, 63: 903-915.

Coate, S. and Loury, G. (1993) "Will Affirmative-Action Policies Eliminate Negative Stereotypes?" American Economic Review, 83: 1220-1240.

Cowen, T. (1992) "Law as a Public Good: The Economics of Anarchy." Economics and Philosophy, 8: 249-267.

Cowen, T. (1994) "Rejoinder to David Friedman on the Economics of Anarchy." Economics and Philosophy, 10: $329-332$.

Cowen, T. and Sutter, D. (1999) "The Costs of Cooperation." The Review of Austrian Economics, 12: 161-173.

Dewing, A. (1914) Corporate Promotions and Reorganizations. Cambridge, MA: Harvard University Press.

Dowd, K. (1994) “Competitive Banking, Bankers' Clubs, and Bank Regulation.” Journal of Money, Credit and Banking, 26: 289-308.

Economides, N. (1995) “Commentary on 'Antitrust Economics of Credit Card Networks'.” Federal Reserve Bank of St. Louis Review, Nov.-Dec. 1995: 60-63.

Evans, D. and Schmalensee, R. (1995) "Economic Aspects of Payment Card Systems and Antitrust Policy Toward Joint Ventures." Antitrust Law Journal, 63: 861-901.

Evans, D. and Schmalensee, R. (1999) Paying with Plastic: The Digital Revolution in Buying and Borrowing. Cambridge, MA: MIT Press.

Fort, R. and Quirk, J. (1995) "Cross-Subsidization, Incentives, and Outcomes in Professional Sports Leagues." Journal of Economic Literature, 33: 1265-1299.

Friedman, D. (1989) The Machinery of Freedom, Guide to Radical Capitalism, 2nd ed. La Salle, IL: Open Court. Friedman, D. (1994) "Law as a Private Good: A Response to Tyler Cowen on the Economics of Anarchy." Economics and Philosophy, 10: 319-327.

Gabel, D. (1994) “Competition in a Network Industry: The Telephone Industry, 1894-1910.” Journal of Economic History, 54: 543-572.

Geddes, R. (2000) “Public Utilities.” In: Encyclopedia of Law and Economics, Vol. III. The Regulation of Contracts. Cheltenham, UK: Edward Elgar, pp. 1162-1205.

Goodhart, C. (1988) The Evolution of Central Banks. Cambridge, MA: MIT Press.

Gorton, G. (1985) "Clearinghouses and the Origin of Central Banking in the United States." Journal of Economic History, 45: 277-283.

Gorton, G. and Mullineaux, D. (1987) "The Joint Production of Confidence: Endogenous Regulation and Nineteenth Century Commercial-Bank Clearinghouses.” Journal of Money, Credit and Banking, 19: 457-468.

Greif, A. (1993) "Contract Enforceability and Economic Institutions in Early Trade: The Maghribi Traders' Coalition.” American Economic Review, 83: 525-548.

Greif, A., Milgrom, P., and Weingast, B. R. (1994) "Coordination, Commitment, and Enforcement: The Case of the Merchant Guild.” Journal of Political Economy, 102: 745-776.

Hanft, N. (2000) "Prepared Testimony of Mr. Noah Hanft." Senate Banking Committee, Subcommittee on Financial Institutions, Hearing on Competition and Innovation in the Credit Card Industry at the Consumer and Network Level, May 25, 2000.

Hausman, J., Leonard, G., and Tirole, J. (1999) “The Impact of Duality on Productive Efficiency and Innovation." Working paper, MIT.

Hock, D. (1999) Birth of the Chaordic Age. San Francisco: Berrett-Koehler Pub.

Katz, M. and Shapiro, C. (1985) "Network Externalities, Competition, and Compatibility." American Economic Review, 75: 424-440.

Katz, M. and Shapiro, C. (1994) "Systems Competition and Network Effects." Journal of Economic Perspectives, 8: $93-115$

Klein, D. (1990) "The Voluntary Provision of Public Goods? The Turnpike Companies of Early America." Economic Inquiry, 28: 788-812.

Lal, D. (1997) "From Planning to Regulation: Toward a New Dirigisme?" The Cato Journal, 17: 211-227. 
Libecap, G. and Wiggins, S. (1984) "Contractual Responses to the Common Pool: Prorationing of Crude Oil Production." American Economic Review, 74: 87-98.

Liebowitz, S. J. and Margolis, S. (1994) “Network Externality: An Uncommon Tragedy.” Journal of Economic Perspectives, 8: 133-150.

Liebowitz, S. J. and Margolis, S. (1995) “Are Network Externalities a New Source of Market Failure?” Research in Law and Economics, 17: 1-22.

Liebowitz, S. J. and Margolis, S. (1998) "Network Effects and Externalities.” In: The New Palgrave Dictionary of Economics and the Law, pp. 671-675. London: MacMillan.

Mahoney, P. (1997) "The Exchange as Regulator.” Virginia Law Review, 83: 1453-1500.

McChesney, F. and Shughart, W. (1995) The Causes and Consequences of Antitrust: The Public-Choice Perspective. Chicago: University of Chicago Press.

National Collegiate Athletic Association (2000) NCAA Division I Manual 2000-2001. Overland Park, KS: NCAA. National Collegiate Athletic Association v. Board of Regents of the University of Oklahoma et al. (1984) 468 U.S. 85.

Neale, W. (1964) “The Peculiar Economics of Professional Sports.” Quarterly Journal of Economics, 78 : 1-14.

Noll, R. (Ed.) (1974) Government and the Sports Business. Washington, DC: The Brookings Institution.

Rochet, J. C. and Tirole, J. (2000) "Cooperation among Competitors: The Economics of Payment Card Associations." Working paper, IDEI, Toulouse.

Rosen, S. (1981) "The Economics of Superstars.” American Economic Review, 71: 845-858.

Rothbard, M. N. (1978) For a New Liberty: The Libertarian Manifesto. NY: Libertarian Review Foundation.

Salop, S. and White, L. J. (1991) "Policy Watch: Antitrust Goes to College." Journal of Economic Perspectives, 5: 193-202.

Schmidtz, D. (1991) The Limits of Government: An Essay on the Public Goods Argument. Boulder: Westview Press.

Smith, V. L. (1980) "Experiments with a Decentralized Mechanism for Public Good Decisions." American Economic Review, 70: 584-599.

Sowell, T. (1994) Race and Culture. NY: Basic Books.

Sprague, O. M. W. (1910/1977) History of Crisis Under the National Banking System. Fairfield, NJ: Augustus M Kelly Publishers.

Stringham, E. (1999) “Market Chosen Law.” Journal of Libertarian Studies, 14: 53-77.

Stringham, E. (2002) "The Emergence of the London Stock Exchange as a Self-Policing Club." Journal of Private Enterprise, 17: 1-19.

Stringham, E. (2003) "The Extralegal Development of Securities Trading in Seventeenth Century Amsterdam." Quarterly Review of Economics and Finance, 43: 321-344.

Sutter, D. (1995) “Asymmetric Power Relations and Cooperation in Anarchy." Southern Economic Journal, 61: 602-613.

Telser, L. (1980) “A Theory of Self-Enforcing Agreements.” Journal of Business, 53: 27-44.

Timberlake, R. (1984) “The Central Banking Role of Clearinghouse Associations.” Journal of Money, Credit and Banking, 16: 1-15.

Tullock, G. (1974) The Social Dilemma: The Economics of War and Revolution. Blacksburg, VA: University Publications.

Tullock, G. (1981) “The Rhetoric and Reality of Redistribution.” Southern Economic Journal, 47: 895-907.

Veitch, J. (1986) "Repudiations and Confiscations by the Medieval State." Journal of Economic History, 46: 31-36.

Zywicki, T. (2000) "The Economics of Credit Cards." Chapman Law Review, 3: 79-172. 